\title{
The Contextual Problem in the Development of Indonesian International Tourism Law
}

\author{
Ida Bagus Wyasa Putra \\ Faculty of Law \\ University of Udayana \\ Denpasar, Indonesia \\ wyasp@yahoo.com
}

\begin{abstract}
Article 7 of the Act has mentioned that tourism development shall cover: tourism industry, tourism destination, marketing and tourism institution. This rule does not include the development of culture as an economic resources of tourism. This paper would demonstrate the situation of the policy, its impacts to tourism, and finally offer a solution for settling the problem. The method used in this study is qualitative content analysis carried on the legal related to the international law on tourism. Data collected through documentation technique covering the library data containing legislation and law. The results show that the Indonesian tourism policy contained a strong energy for destroying its economic resources. In accordance to McDougal's policy-oriented theory of law the situation has firmly been caused by the disconnection between the policy and its context. The less rational approach of the policy construction has caused the policy failure to cover the fundamental aspect of tourism, the economic resources of tourism. This failure has caused the development of tourism contra-productive. The more successful the development of tourism, the more threatened the economic resources of tourism and the threatened the sustainability of tourism.
\end{abstract}

Keywords-contextual problem; development; international tourism law

\section{INTRODUCTION}

Article 7 of the Indonesian Tourism Act, Act Number 9 of 2009 (hereinafter: Tourism Act) has clearly stated that the coverage of the Indonesian tourism development are: tourism industry, tourism destination, marketing, and tourism institution. This Act has totally ignored the position and role of culture in its newest position and function ever, as an economic resources. The empowering of all aspects of tourism as mentioned in article 7 might be resulted in an exploitation and destruction against the capacity of the culture. The development of all aspect of tourism, except culture, would increase the power of tourism and its capacity on using its resources. If the power of tourism on using its resources increases, while the capacity of its resources on supporting the needs of tourism is left in a constant situation, then tourism will certainly turn into a predator against its resources. If this situation continuously existed without any policy intervention for recovering the impact of the exploitation, the culture might turn into depletion and no longer performs it capacity. All this story will certainly end in a miserable episode of tourism, the unsustainability of tourism, and the rest will be the story of the drop of the government's, the private sectors', and the people's income.

The situation is contrary to the purpose of tourism development as reaffirmed in article 4 of the Act which states that the purposes of the development of tourism are among others: increasing the economic growth, promoting the welfare of the people, shorting poverty, preventing unemployment, preserving natural resources and environment, and promoting culture. The depletion or even the destruction of culture would not present an opposite result of development. Therefore, a policy intervention for saving the role and function of culture as an economic resources of tourism and for keeping the sustainability of role and function of tourism in the life of state is firmly needed. For now, such kind of policy has caused an overstress of space in some regions of Bali, such as: the south of Bali region, Ubud, and any other tourism regions in Bali; destroying rivers and land; decreasing water supply resources; and suffering the economic capacity of the people of the tradition al village on maintain or recovering their culture.

\section{METHOD}

This study belongs to a normative approach. Statute and conceptual approach to legislation were applied in collecting and making the sense of the data. Qualitative content analysis was used in analyzing the content of the underlying and related law to international national tourism of Indonesia. Related literature was collected through conducting a library search to obtain the main secondary data, whereas the primary data was obtained from field research by collecting the underlying legislation on international tourism.

\section{RESULT AND DISCUSSION}

\section{A. The structure of the Problem and Its Implication}

The culture of Bali is the culture of the traditional communities in Bali. The culture of Bali is belonged to and maintained daily by the owner of the culture, the traditional community. They inherit the culture form their ancestor and maintain it under their own expense. The culture is the economic reason of the Bali's tourism. The culture produces tourism and the tourism produces income for the government and the private sectors. When the traditional community produces culture, the culture produces tourism, and the tourism 
produces income, the income produced by tourism does not flow to the traditional communities who owned and maintained the culture. It flows to the government and private sectors even all governments and private sectors of the world whose companies or private sectors taking a part in the Indonesian tourism. The picture of disconnection between the culture or the culture's owner and maintainer with the income of tourism has shown a kind of exploitation over the culture. The issue of injustice shall also arise from such kind of treatment.

There are some 1.468 traditional community in Bali. They have their own territory, people, and government which under the Constitution is qualified as an autonomous community. Hence, they are granted rights to own their own community territory, people, and government. The Constitution granted an authority for governing their domestic community affair, including rights to produce community law for managing their domestic living. They are under obligation for managing and expensing their own community business, including for managing their cultural heritages. There are some at least three temples in each village, known as the village temples. Each of the temples shall perform ceremony at least two times a year. At each of the ceremony, they shall spent at least 100,000,000 (one hundred million) IDR. So, for such kind of ceremony the whole traditional community shall spent some 880,800,000,000 (eight hundred eighty billion eight hundred million) IDR per year. Instead of any other type of daily ceremony that shall be performed daily by teach family of the community member. Each family commonly spent at least 10,000 (ten thousand) IDR per day. Therefore, if there are some two millions families holding Hindu Religion then there shall be some 7,200,000,000,000 (seven trillion two hundred billion) IDR shall be spent per year by the family of the community member. If the community expense added to the family cost, there shall be some 8,080,800,000,000 (eight trillion eighty billion eight hundred million) IDR shall be spent by the traditional community per year, both the community and the family the member of the community. This cost has not included any cost for territory, management, and heritages maintaining and recovering. This huge amount of the culture cost of maintenance has never been mention in the public management of the Indonesian tourism [1].

This cost, in term of economic theory shall be considered as a social investment of the traditional community on managing the economic resources of the tourism. When it produces tourism and the tourism produces income, the income does not flow to the traditional community. In accordance to Marx's economic theory, such situation shall be qualified as an exploitation. Malthus added, the government needed to intervene the situation for keeping the works of economy. There shall be a return for any investment performed by anyone. Under economic theory, there shall be no investment without no return. The figure of this exploitation may be drawn up as follows [2]:

\section{THE FORM OF CULTURE EXPLOITATION}

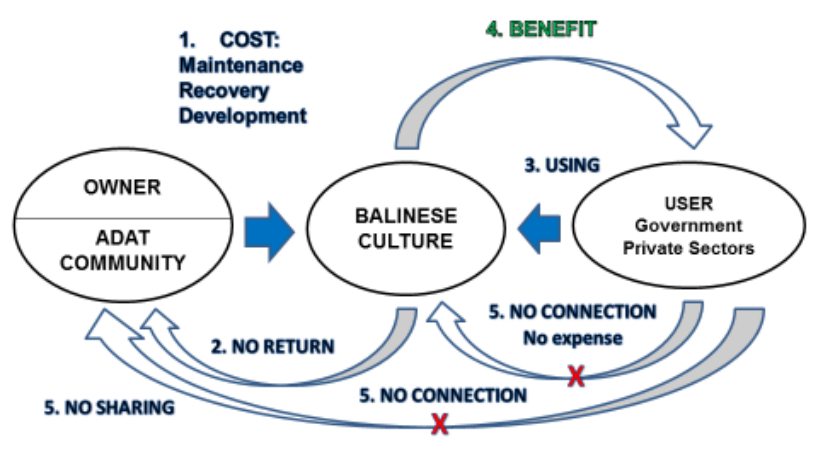

Fig. 1. The form of culture exploitation.

For recovering the rights of the traditional community, there shall be a channel between the traditional community with tourism or the user of culture who enjoy the benefit of the existence of the culture by means of enjoying the outcomes of the tourism.

\section{B. The Absence of Contextual Approach}

Context is the context of the policy. It is the community where the policy shall be applied or to whom the policy will bring impact [3]. In accordance to the principle of democracy, any state who claimed their self as democratic state, shall be under obligation to explore the expectation of the context and then absorbs it into the policy developed by the State [4]. Such situation in Bali draws up the nature of issues containing in the policy which mostly rooted in the policy development process. Professor McDougal qualified such policy as a disconnecting policy with its context. The policy has totally ignored the existence, the position, the role, and the function of the traditional community in the whole policy process. They also ignored the needs or expectation of the community as the context of the policy. He suggested the policy maker to solve the problem by means of absorbing the expectation of the community into the policy.

\section{The Sporadic Policy}

The other source of the problem is the structure of the policy which is not well structured. The World Trade Organization (WTO) has qualified tourism as a trade in services. It is a system which consisted of two sub-system such as the internal system and the external system. The internal system is the market system, consists of the services providers, the consumers, and the services as the subject of the tourism business transaction. The services providers in the internal system are consisted with all kind of tourism services, such as the travel services, the accommodation services, the $\mathrm{F} \& \mathrm{~B}$ services, including the brokers, tourism information services, etc. The external system is the non-market system. It consists of all components in the external system which affecting the work of the internal system, such as, governmental institutions, political institution, private sectors, NGO's, communities, etc. [5]. The Government of Indonesia has adopted various kinds of 
policy for governing the internal and the external system. However, it has not been managed in an integrated system of policies guided by an integrated vision and mission of the tourism targets. Such kind of the policy structure has caused all policies sometimes turn into policy conflict, overlapping, or suffering each other. All this situation has turn tourism trade performance into a contradictive process.

\section{The Policy Recovery Scheme}

1) The needs and concept of recovery: The first needs of recovery is to reconstruct the policy system of tourism for capturing the whole aspect of tourism. This shall start from redefining tourism, developing tourism policy paradigm, reconstructing the policy structure and scheme, and setting a proper program and action program under such structure of policy. Tourism shall be defined in accordance to its newest facts, a trade in services, and shall be referred as the basis for the development of its policy. Such new definition shall be set as the basis for the development of policy paradigm and the policy structure. Hence, tourism may not be defined other its new concept, tourism as a trade in services system which covers two sub-systems, the internal system and the external system. The internal system is a market system which covers the services suppliers, the consumers, and the services itself as the subject of tourism trade. The external system is the nonmarket system which covers the whole components having potencies for affecting the work of the internal system. It at least covers the public institutions, the private sectors, the political institutions, the NGOs, and the communities. Hence, the policy shall define the position and function of the subsystem and shall determine the management system of each of the system including its relation. The Act might cover the system, but it less constructive. This has simply caused the policy maker ignoring the very fundamental component of tourism trade in services, the culture. This fatal ignorance would simply end in the unsustainability of tourism.

Culture, the economic resources of tourism, shall also be defined well referring to its natural facts. It shall carefully prevented from its bias with any normative description. Culture, in term of its new position and function in the works of tourism, shall be accurately defined under its position and function related to tourism. Under such requirements, culture shall be clearly and simply drawn up from its existing position and function in its context. Under its existing, culture as an economic resources of tourism in Bali is the culture of the traditional community. The traditional community in Bali is the owner and the maintainer of the culture. They live consistently with and take care the culture under their own expense. Under Smith economic theory, such expense for maintaining culture shall be considered as an investment and an investment shall require return. Any investment with no return, under Marx's economic theory is considered as an exploitation, an unfair trade practices [6].

As the economic resources owns and maintains by and resides in the traditional community, the development of tourism economic resources may be simply qualified as equal to the development of the traditional community. The first structure needed for flowing return of investment from the market system of tourism into the site of its resources is the channel for connecting the traditional community and the tourism. It might be developed by the Government or any other institutions, including NGOs and the universities. It may also be developed by an institution representative of the communities, such as the Majelis Desa Pakraman (the Traditional Community Assembly) with an institution representative of tourism business community, such as the Bali Tourism Board. The channel for return of investment between the Government and the communities may be developed under the facilitation of the Government.

The return of investment of the traditional community on maintaining their culture from the Government may be formed in a grant which is in particular provided for supporting the maintenance of the culture performed by the traditional community. While, the return from the private sectors may be formed in a special financial supporting scheme or under its Corporate Social Responsibility (CSR) program. So, the Government and the Bali Tourism Board or any other business community shall actively take position on supporting the traditional community as the traditional community never considered itself as an economic institution, but a cultural institution. Lacks of speed on taking position by the Government and the business community institution might silently be caused a depletion of capacity of the traditional community on maintaining their culture in reference to the huge cost of maintenance expense. While, the traditional community has no regular financial resource.

2) The community-based tourism: There is a model or scheme of tourism business which possibly produces benefit both for the company and the community in the same time which has been formulized in the concept of community based tourism (CBT). The CBT is a reality in Bali. It has been practiced by a company named PT Taman Sari, a limited liability operating a tourism resort in the village of Pemuteran in the North West of Bali. This company has operated the concept of CBT developed by Anak Agung Prana, the owner of the company, a Balinese who has practiced the concept of CBT since twenty years ago. He organized his business under a community-based tourism concept. He has developed his own model of CBT for satisfying the company's expectation and in the community in the same time. He secured some $30 \%$ of his company's profit for shared with the villages around the company. He does not accept any single money from the community and he also has no investment agreement with the community, but he consciously, voluntarily, and regularly share his company profit with the communities around his company in total $30 \%$ of his profit. He empowered the community capacity and take them as a worker in his company. This model has positively supporting the community on handling their function on maintaining the culture. The people in the village might also conducted business which supporting the needs of the resort. This model has successfully works for years and it has transplanted into another model of community-based tourism in the region of Badung. The CBT has proven satisfying both the company 
and the community in the same time which turn into the support of the community to the company. The support of the community to the company has rose up a strong promise of sustainability to the work of the company and so the tourism. This kind of CBT is excellent for balancing the contribution of the community to tourism and so reversely. However, a businessman like Anak Agung Prana is rare.

3) The policy recovery model: Those all kind of schemes of tourism business seem promising improvement to the work of tourism as long as the schemes has been adopted in advance by the Government's tourism policy. Hence, the recovery of tourism policy shall be started from the development of the definition of tourism and then followed with determination of tourism policy paradigm, and formulation of the structure and substance of the policy. It shall be firmly bring into mind that accepting the newest facts of tourism and adopting the newest approach of policy development is a prerequisite of the development the rational tourism policy. Hence, the adoption of the contextual approach is certainly suggested and absorbing all concepts of tourism which has been developed under the newest fact of tourism is strongly suggested. In addition, all schemes of tourism recovery are also strongly suggested. Under such comprehensive approach and construction of policy the Indonesian tourism policy might be recovered and so its role and function in maintaining the sustainability of tourism.

\section{CONCLUSION}

The Indonesian tourism policy contained a strong energy for destroying its economic resources. In accordance to McDougal's policy-oriented theory of law the situation has firmly been caused by the disconnection between the policy and its context. The less rational approach of the policy construction has caused the policy failure to cover the fundamental aspect of tourism, the economic resources of tourism. This failure has caused the development of tourism contra-productive. The more successful the development of tourism, the more threatened the economic resources of tourism and the threatened the sustainability of tourism. The more successful of the development of tourism might cause the more destroyed the economic resources of tourism. The worse quality of the policy might be recovered by means of recovering the approach of the policy setting. For the shake of this mission, the adoption of the contextual approach in the recovery of the Indonesian tourism policy is strongly suggested.

\section{ACKNOWLEDGEMENT}

The author would like to thank all the parties who have helped and contributed in the writing of this article, both those who contribute in the form of funding and critical ideas. Hopefully this paper can be useful theoretically and practically for the addition and development of knowledge, especially in the field of legal science.

\section{REFERENCES}

[1] I. B. W. Putra, Analisis Konteks Dalam Epistemelogi Ilmu Hukum: Suatu Model Penerapan Dalam Pengaturan Perdagangan Jasa Pariwisata Internasional Indonesia (Contextual Analyses in the Science of Law Epistemology: A Model of Application in the Regulation of Indonesian International Tourism Trade in Services), University of Udayana, 2015.

[2] I. B. W. Putra, Landasan Teoritik Pengaturan Pelestarian Warisan Budaya: Bali Sebagai Suatu Model (Theoretical Basis for the Regulation of the Preservation of Cultural Heritage: Bali as a Model), Udayana University Press, 2017.

[3] I. B. W. Putra, Teori Hukum Dengan Orientasi Kebijakan (Policyoriented Theory of Law), Udayana University Press, 2016.

[4] A. R. B. Seidman and N. Abeysekere, Legislative Drafting for Domestic Social Change: A Manual for Drafters, Copy Rights by Authors, 1999.

[5] Baron, D. P., Business and Its Environment, Prentice Hall, New Jersey, 2002.

[6] Skousen, M., Teori-Teori Ekonomi Modern (The Making of Modern Economics), Prenada, Jakarta, 2006. 